\title{
(P-8)
}

\section{A Study on Mangrove Diversity in Vankaalai Estuary, Mannar}

\author{
B. Nirooparaj ${ }^{\text {* }}$, K. Krishnanantham ${ }^{2}$, G. Puveenthiraraja ${ }^{3}$, A. Arulananthan \\ ${ }^{1}$ Regional and District Aquaculture Extension Office, National Aquaculture Development Authority, \\ Vavuniya/Mannar, Sri Lanka \\ ${ }^{2}$ GEF/IFAD-PCZRSM Project office, Trincomalee, Sri Lanka \\ ${ }^{3}$ Tropical Fish International (Pvt) Ltd, Sri Lanka \\ *nirooparajb@gmail.com
}

\begin{abstract}
The mangrove along Vangalai coastal area associated with numerous marine flora and fauna communities remained rarely studied. The present study was carried out during the period from April to July 2015 to document the status of mangrove distribution of selected sample sites in Vankaalai estuary, Mannar. Seven belt-transects of $10 \mathrm{~m}$ in width were laid perpendicular to the shoreline. Data were collected on floristic composition and tree height along the plot of each sites. Mangrove Diversity and evenness were calculated using Shannon-Wiener diversity index and Pielou's evenness index respectively from each sub-plot $\left(100 \mathrm{~m}^{2}\right)$ in belt transects.

Results revealed that six mangrove species such as Avicennia marina (Avicenniaceae), Rhizophora mucronata (Rhizophoraceae), Bruguiera cylindrica (Rhizophoraceae), Sonneratia alba (Sonneratiaceae), Excoecaria agallocha (Euphorbiaceae) and Pemphis acidula (Lythraceae) were recorded from the mangrove forest in study period. Further, 5 major mangrove associated plants were observed in the study period. The greatest mangrove diversity (1.296) was observed in sub-plot 14 of transect 5 and the lowest mangrove diversity (0.453) was recorded in sub-plot 3 of transect 1 . The results showed that A. marina was the dominant species. Species diversity (H') of whole mangrove area studied was 1.155 and evenness (E) was 0.645. It revealed that Vankaalai lagoon should be protected since it consists of high biological diversity of mangroves.
\end{abstract}

Keywords: Mangroves, Diversity, Evenness, Transect 